Jelena Šesnić

University of Zagreb

\title{
Re-centering the History of the Americas: Toni Morrison's Beloved and A Mercy
}

This article discusses the status of Toni Morrison as an American writer who consistently foregrounded African American history and experience and acted during her long career as a public intellectual. Morrison's writerly agenda has been to delve into the epistemological origin of constructions such as race and blackness, placed in the context of their historical manifestation, such as transatlantic slavery as manifested in Morrison's two most striking historical novels, Beloved (1987) and A Mercy (2008). Writing slavery, as a way to re-write the United States' history and probe its dark spaces, places Morrison's texts in a long line of nineteenth-century slave narratives, and in particular their twentieth-century avatar, the neo-slave novel, which strives to historicize slavery from the sufferer's perspective. In the process, Morrison creates a "resistant text" (Sommer) requiring the reader's imaginative and ethical engagement and refusing to fill in all the gaps. That the haunting of slavery still requires imaginative, historical, and ethical engagement, like the one accorded it by Morrison, is a fact of U.S. American social life to the present day.

Key words: the historical novel, the neo-slave novel, transatlantic slavery, Toni Morrison, memory, history

[Toni Morrison's] work is rooted in history and pulls beauty from some of its most grotesque manifestations. But that beauty is not fantasy, and so it should not be surprising that she ranks among those who understand the hold that history has on us all. 


\section{Margins and Centers}

Toward the end of an interview for Uncensored, a documentary feature of the Australian Broadcasting Corporation produced in 1998, Toni Morrison allows herself to pronounce on the cumulative effect of her writing up to then: "I stood at the border, and claimed it as central, and made other people come over to it" (Uncensored: Toni Morrison). The cluster of spatial metaphors of borders, margins, and centers has been one of the organizing cognitive vehicles applied to disciplinary re-arrangements in critical and literary studies in recent times. ${ }^{1}$ Still, refraining from the more theoretical underpinnings of this shift in the humanities, I would like to linger for the moment on the more specific implications of the metaphor. As I see it, Morrison's claim is more profound and encompassing than a trendy change of critical paradigms in literary studies. What Morrison is more concerned with is the sponsoring of literature, specifically her own and that of other writers of color, as a cognitive vehicle for its capacity to freely and unselfconsciously as perhaps never before explore the implications of being human (for characters nominally designated as marginal and de-centered). ${ }^{2}$

Hence she sees her writing to be largely indebted to the historical and historically conditioned status of marginality tagged onto the black people in the United States and professing both a simple and a profound claim-literature is a linguistic and aesthetic activity that primarily concerns itself with human experience as such-and from that perspective makes it secondary whether an experience, to be aesthetically meaningful and stirring, is "mar-

1 Ever since the early efforts at American literary canon expansion and reorganization, energized by a host of developments ranging from feminist to ethnic to postcolonial, hemispheric, and globalist perspectives, spatial metaphors have provided a cognitive frame for addressing the issues of knowledge production, legitimation, and dissemination. Even one of the latest attempts in this vein, Caroline Levander's intervention into the future of American literary studies and American literary history, finds itself drawn to a cluster of spatial metaphors in order to elucidate its key arguments.

2 For additional implications of the margin/center binary, see Tally (1-7). 
ginal" or "mainstream," borderline or central, ultimately, black or white. So the notion of literature that Morrison evokes here engages her simultaneously on several levels, from the universal designation of "writer" to more particularized variants such as American, African American, and female writer. These levels interact even as Morrison then mischievously adds that she occasionally feels like a Russian author with respect to American literature-such is her sense of divergence or displacement from the national mainstream (Uncensored: Toni Morrison). The trajectory that she thus outlines for her works, as I further read into her responses to the questions posed in the interview, is to allow, after the first transition has presumably been made-that from the center to the margin - the next shift to take place. This latter shift aims to render, first experientially and aesthetically but then also ontologically, meaningless the division into a central and a marginal kind of experience, especially when and if it attaches to the idea of "race" or "color." That this is a fairly recent achievement is remarked by Linda Wagner Martin, who contends that, even as late as the mid-nineteen-eighties, U.S. readers "had only just begun to accept African American characters as complex individuals-especially African American women characters" (69).

Morrison destabilizes the reader's sense of the fixity of cognitive categories, accruing the concepts of race, color, color line, blackness, and whiteness, while undermining their respective hierarchy and status in a received epistemology of race. This requires no less than re-examining the very foundations of modernity, as David Theo Goldberg argues: " $[\mathrm{R}]$ ace has been a constitutive feature of modernity, ordering conceptions of self and other, of sociopolitical membership and exclusion" (148). Put differently, if a so-called marginal experience gets embedded in a set of culturally heavyweight representations (such as the historical genre in the case I will be arguing here), this renders problematic the entire categorial system commanding the meaning of individual elements within it. This wavering between specificities while using them to tackle the universal, which ultimately dismantles yet another assumption, of what constitutes universality as opposed to particularity, 
is the way Morrison uses the seemingly insignificant and off-center to delve into persistent, complex, and enduring problems of being human, and acting human in history. She proposes quite defiantly and with assurance born of her writing that this dilemma for her centers on female, black, and socially marginal characters in a devolving history of the Americas, of the mistitled New World giving rise to the "elegiac vision of the pastoral" (Sandy 35). Mark Sandy finds in the types of characters that Morrison takes as conduit for telling her stories precisely marginal men and women, harboring grief and loss, the kind of common figures used by William Wordsworth, both writers thus introducing "anti-pastoral elements" (35) as a reaction to the implacable historical and social forces constraining their characters.

The prerogatives of historical perspective and its fictional form are indicated in the view of the genre offered by Georg Lukács. The historical novel is meant to combine different types of individuals, the "world-historical" and ordinary, insignificant, according to Lukács (231-32). The point is to individualize and personalize overwhelming social and collective events, and to refract them through an individual's experience, perspective, and psychology. It is thus "the historical novel's 'middle-of-the-road' hero" (232) that should reflect the spirit of the age. The (historical) novel is also under a special obligation to manage the tension between the public and the private, since "by representing a limited section of reality ... it [the novel] aims to evoke the totality of the process of social development" (237). The point is thus to render an idea of history that will be different and distinct from historiography, the epic, and the historical drama, and yet distill the significance of the past. A further point for Morrison is to render a story generated by a specific ilk of characters and make it count as history, thus meaningful for the entire nation.

This intervention, the inherent possibility of the historical novel to cultivate a different breed of characters, is seconded by Philip Fisher's discussion of the specific cultural work, a contribution that the historical novel is 
meant to proffer to the national culture. ${ }^{3}$ In that respect, arguably, the historical novel's successor and contender in both twentieth-century African American and national culture is the neo-slave novel, a designation pertinent both to Beloved (1987) and A Mercy (2008), the two novels dealt with in this argument. Hence, it is the neo-slave novel and its historiographic inclination that proposes to do the comprehensive cultural work of processing slavery in the ambit of the national cultural imaginary. ${ }^{4}$

Perhaps still one of the most poignant images of the imbrications of the so-called universal and the so-called particular, of the presumably grand and small narratives, is encapsulated in the string of episodes in Beloved that Sethe's, the female protagonist's reported speech and interior monologues sporadically reconstruct for us. This particular instance refers to Sethe's obsessive remembering of the ink which she processed from indigo to be used by the owner of the Kentucky slave plantation, Sweet Home, where she lives together with a band of male slaves. Sethe is plagued by the memory since she belatedly understands the full implication of the use to which Schoolteacher, a sadistic master, puts the ink: not incidentally, the ideology of racism noted

3 See especially Fisher's Introduction and Chapter 1, explicitly dedicated to the historical novel in early nineteenth-century American literature.

4 For a general framework, see Eyerman 2001; McDowell and Rampersad 1989. For more particular readings of Beloved in the above-mentioned frame, see Rody, esp. 3-16, 19-104; Rushdy, "Daughters"; Rushdy, Neo-Slave, esp. ch. 2. Respective plot summaries indicate the historical impulse behind both novels: Beloved covers the period from the 1850 s to 1873 , thus from slavery to Reconstruction, following the story of Sethe, a fugitive slave who, pressed by the posse of her pursuers, slays one of her children and spends the rest of the novel expiating for her deed. Additionally, Sethe's character is based on the historical figure of Margaret Garner (Henderson 82). Morrison masterfully complicates the relationship between the story and the plot. A Mercy wavers between the past and present in the voices and perspectives of different characters but mostly covers the period of the late 17 th century in the mid-Atlantic colonies and the irreversible setting in of slavery and slave codes. The focus is on Florens, a slave girl presumably given up by her mother, a fact that is taken up only in the novel's final chapter. As identified by scholars, the historical kernel here is Bacon's Rebellion (Montgomery 2; Wagner Martin 156). Here, again, it is as much about story as about narration. 
in ciphers underlies the transformation of the deceptively idyllic plantation into a hellhole soon after his arrival and takeover, and underlies his educational and instructional efforts both on his pupils and on the slaves. ${ }^{5}$ Ink, writing, and knowledge-production are linked in one of the most striking metaphors in the novel attesting to the historical rise of plantation slavery in the Americas.

As Morrison claims in the above-mentioned interview, racism is propped by science and ingrained in the education that we receive; it is thus written in ink by which a culture purports to enlighten, cultivate, and inform. The ink, with its dark tinge, however, works as an interesting double to another, white fluid, Sethe's mother's milk, which serves as a counterpoint to the literally and symbolically dehumanizing effects of the ink. Morrison does not simplify or corral the manifold implications of the images: the ink is, especially in comparison to the whiteness of the milk, apparently black, dark; it is produced by Sethe but, as are other products of slave labor, immediately alienated from its producer, who has no control whatsoever over its use or effect, so that it is fairly impossible for Sethe to evade the devastating consequences of being put down in black ink. On the other hand, the whiteness of the milk allegedly accrues to Sethe simply and incontrovertibly as an extension of her biological, reproductive labor, which by definition could not be taken over, expropriated from her as a mother, or denied her child. This logic, however, is patently untrue under slavery. The whiteness of the milk might guarantee the child's survival but is, due also to the symbolism of its color, open to manipulation and appropriation by the whites $(16,190)$. Its very whiteness renders it symbolically noxious and potentially devastating for Sethe and her child, Beloved. Blackness and whiteness, the creative and the destructive, the social and the personal intermingle on the level of key images in the novel.

5 Morrison, Beloved 35, 183-84, 257. All subsequent references to the novel will be cited parenthetically in the text. 
For Florens, one of the protagonists and intradiegetic narrators in $A$ Mercy, it is shoes, or rather her craving for them, that signal her incipient femininity, her differentiation from her mother, and her state of bondage. Shoes draw her out as an available sexual object for her masters, and thus dramatize the point where she severs her ties with childhood and her mother's nurturing care. Shoes become an object of aesthetic import, a correlative of the character's emotional and cognitive state, but also an item functioning in a specific emotional and corporeal economy of slavery: Florens's dainty feet protected by shoes might become precisely her most precious and thus most damnable commodity. To save her from that doom, her mother induces a somewhat friendly disposed trader, Jacob Vaark, to take Florens away in lieu of the debt owed to him by her predatory owner, D'Ortega. The economy of a particularized literary motif is what Morrison uses to tackle grand issues. Philip Page thus observes "Morrison's lyrical repetition or near-repetition of phrases and images," which he considers within a larger ambit of "circularity" (142).

\section{Redrawing the Literary Field}

To continue with the key metaphor from the beginning, a similar tension between the margin and the center is at work also in Morrison's non-fictional writings. Cheryl Wall conveniently recapitulates Morrison's indubitable stature as a pre-eminent writer and critic (139-48). As a literary critic, Morrison has become a trailblazer, in particular with her study of the entanglement of literary whiteness and Africanism in classic works of American literature that apparently do not concern themselves with the notion of race, or if so, do it only marginally (Playing). On the contrary, she has contributed to the idea of whiteness as contingent on the expression of blackness as its underside-moral, ethical, philosophical, or material. Moreover, she has insisted that such an intermingling constitutes an abiding strain in American literature thus reflecting the nation's obsession with the issue of race, whatever the period, genre, or author. This intervention is important not only as a substantive and convincing comment on American literature and the logic 
of its historical development but also as a strategic move on Morrison's part that should enable her and other designated authors some respite from the implied task of handling presumably secondary and marginal issues. In an interview with Cecil Brown, Morrison contends that, until recently, African American writing has been seen to serve specific extraliterary goals, while often being evaluated for the presence or absence of externally imposed criteria. Some of these were, routinely, the literature's protest tone, social consciousness, and malleability to some socially generated expectations placed on the black characters (Brown and Morrison 455). Consequently, if the entire American canon is shown to be invested in either exorcising or incorporating the idea of color, then the African American artist is simply on the forefront of what everybody else is doing.

As part of her perspicuous and comprehensive redrawing of the critical and fictional field within which her text and similar ones unfold, Morrison bridged the gap that she initially perceived between the burgeoning production of black female texts in the late 1960s and the 1970s and the non-existent critical reflection on that production at the time (Stepto and Morrison 485). As part of her critical perspective, it is important to restate one of the lasting claims that Morrison makes about racism as a particular form of "racial ideology," labeling it a constitutive part of the project of conquest and appropriation of the New World (Berlin 9). A particular racial thinking, crystallized as racism, is necessarily a condition for the history of the New World to start unfolding and the engine behind a huge political-economic project that spawned the Americas. In his comprehensive study of the first two centuries of North American slavery, Ira Berlin unfolds the particulars of the way race, in tandem with class, becomes a salient point in determining and maintaining the institution of slavery. Such codification of color is one of the indications of the transition from "societies with slaves" to "slave societies" (Berlin 9, 1792), a process appropriately recorded in A Mercy.

In addition, let me proceed to outline a more specific argument 
claiming that the novels central to my discussion of Morrison's work, namely, Beloved and A Mercy, are to be considered as historical novels, among other applicable generic categories. In the second instance, these are the novels of New World slavery that preeminently occupy in the national imagination a space of a still inchoate commemoration and memorialization of slavery. At the spot where the representation of the past and the historicization of slavery intersect, as pointed out by Rushdy and Rody, among others, is the birthplace of the neo-slave novel, a post-Civil Rights genre that derives from the ingrained tradition of slave narratives as the first major literary expression of African American sensibility (McDowell and Rampersad vii-xiii).

It is noted in literary historiography that African American writing has only fairly recently engaged more deliberately with the theme of slavery, in whichever genre or form. A reason for this deferral is conjectured by Ron Eyerman's study of the phases of incorporating slavery into the African American and American cultural spheres. He considers slavery as "cultural trauma" for generations of African Americans that consequently demands to be represented and modulated in the process (Eyerman 23-57). With Morrison and other like-minded writers, it finally becomes possible to consider the historical novel of slavery as partaking of the mainstream cultural climate, or at least finding itself in a position to do so. Hazel Carby articulates this concern: "[W] hat interests me the most about these historical novels is the choice of slavery as a period in which to set historical fiction and how that choice itself is generated from particular cultural conditions" (128). Carby proceeds to analyze one of the first examples of the genre of the neo-slave novel, Margaret Walker's Jubilee, conceding the novel's importance: “Walker's representation of slavery is her philosophy of history, which is to be understood as the necessary prehistory of contemporary society" (Carby 136). The similar could be argued about Morrison.

Let me further reinforce the argument of the cultural and political import of the neo-slave novel - precisely as a mode of remembering and 
memorializing - by drawing on a fairly recent debate in the United States pertaining to the construction of a national museum of slavery. Interestingly, there are museums of slavery, but they are located elsewhere, not in the United States but, rather, in Liverpool, England, itself an important post in the international slave trade through the centuries. Conversely, it has been noted that there are a number of museums and memorials of the Holocaust in the States. The comparison is not meant to conflate the two events, and even less so to deny the need for their appropriate institutional marking, but to point to a strange contradiction of American history - an event, such as the Holocaust, that strictly speaking does not belong to national history, finds its place in the national imaginary in quite engaging terms and on a respectable scale. However, slavery, which has indubitably shaped not only the country's past but also inflects its present, is not seen fit to be commemorated by a single institution of national stature. According to some critics, the extant local, regional or period-based museums of African American history in the States should fill the void, but this clearly does not amount to the same thing. Such a telling gap in the national process of remembering, as described by Eyerman, is what Morrison has in mind as she deplores the nation's refusal to remember or its adherence to selective memory. ${ }^{6}$ She acknowledges that, except for the elusive testimony of slave narratives, she lacked precedent for the kind of story she pursued in Beloved (Morrison, "A Bench" 4, 40-41; Playing 50-51). Thus the intent behind Beloved was to show how history is tangential to mem-

6 Consider the foiled project for the founding of the national museum of slavery and the role that it should have played in the reorganization of national memory ("The United States National Slavery Museum"). In the meantime, in 2016 President Obama dedicated the National Museum of African American History and Culture at the navel of national historical memory on the Washington Mall, which figures as a pre-eminent lieu de mémoire, in Pierre Nora's words. However, to sharpen our perspective, consider how the museum's aim is to incorporate the history of slavery within a larger narrative, in contrast to one of the most recent attempts enacted at the Whitney Plantation Slavery Museum (a private initiative), whose mission is to offer an unflinching portrayal of slavery: "While other museums may include slavery in their exhibits, the Whitney Plantation is the first of its kind to focus primarily on the institution" (Rosenfeld). 
ory and how such an interdependence is crucial when it comes to converting slavery from memory to history, from the personal to the collective, from the particular to the emblematic (Fabre and O'Meally).

The politicized moment of the recognition of Beloved is already part of Morrison lore, a well-rehearsed episode in late-twentieth century American literary history in which a number of black authors, scholars, and intellectuals expressed their concern with the tendency of the mainstream culture to bypass parts of the less palatable historical record, which thus gets silenced and marginalized ("Black Writers in Praise of Toni Morrison"; Mitgang). One could argue that the appearance two decades later of A Mercy, also crucially concerned with slavery, happened as a politicized moment too, albeit with a different slant, coinciding with the historical election of Barack Obama as the first black president (Nicol and Terry 7; Tedder 144-45). Similarly, we could argue that the current re-reading of these two novels partakes in the present upheaval caused properly speaking by the historical haunting of race in America. Looking at the country today (2020), Morrison's use of ghostly figures as ciphers of the unaccounted-for burden of history, seems prescient, as we witness the resurgence of racial feelings supposedly laid at rest. As suggested by Keith Byerman, Morrison remains "the writer most thoroughly engaged in the quest for a fully historicized Afro-American narrative discourse," especially since "[a]ll her novels demonstrate the impact of the personal and communal past on the present and show how social, economic, and cultural realities of a particular time and place shape the identities of her characters," casting them in the process as representative national subjects (814).

That there should be such a connection is argued by Doris Sommer, who works with the generic mold of historical writing in the context of what she designates as "minority writing in the Americas" (Proceed). In an earlier study, Sommer insists that creolized cultural forms in the Americas have produced an alternative historical fiction pertinent to new national identities arising in the zones seen marginal to Europe. She builds upon Benedict 
Anderson's depiction of the forms of print capitalism used by the carriers of creole nationalism in the New World nations (Foundational 1-29). The minority writing across the board that Sommer analyzes in her study consciously appropriates forms of historical imagination for a new phase of imagining the nations in the Western hemisphere. Beloved, a specific focus of Sommer's reading in her second book, testifies to the change of focus, just as is later the case with A Mercy (Proceed 160-84). The neo-slave novel has become a form that crystallizes social and historical realities of long duration, providing ways in which some events may be epistemologically transposed from the past into history (either as discipline or as literature).

Morrison will not allow us to disregard the implications of imperialism and racism for the course of New World and global history, and for their ties to the present. In her novels she, thus, figuratively delineates what in another context Michael Omi and Howard Winant have termed the formation of race on the macro-social level. As the Europeans meet their others, Omi and Winant explain, a comprehensive and far-reaching project of racialization gets under way. The category of religion, obviously a relic from pre-Renaissance times, fails to register the differences, so other descriptors must be used, among them primarily the epidermis (Omi and Winant 61-64). In fact, one of the arguments of placing globalization in the early modern period claims that its rise is contingent on and implicated in the conquest, despoiling, and continuous extraction of resources from the Americas and other marginal zones from the Western perspective (Blaut). In his reading of geography in Toni Morrison's novels, Beavers queries the intersection of space, place-making, and agency to argue for specific political imaginaries of slavery that Morrison intends (1-22). We should therefore consent to a reviewer's pronouncement that both Beloved and A Mercy tackle the nation's, America's "original sin" (Gates).

In A Mercy, we see the social category of race arising virtually before our eyes in the testimony rendered by Florens's mother, the first one of the 
family to be brought from Africa. The process of her (sexual) breaking inher sexual trauma-is at the same time the moment where her racial identity ("negrita") is announced and established. ${ }^{7}$ From there it still does not unequivocally proceed that race clinches the slave status, or that the two are inextricably linked. However, this process has been prepared, Laura Doyle suggests as she considers the narrative of the racialization of freedom and nationality in the trans-Atlantic world (Freedom's). Specifically, the notions of freedom, civic status, and agency are linked to the Anglo-Saxons, while the other groups exhibit these features only marginally, if at all (Mudgett 68; Cox 107).

Even though by plot indicators A Mercy predates Beloved (in terms of narrated time, the prehistory of slavery in $A$ Mercy, and its aftermath in Beloved), there are ways in which it in fact replicates some of the lessons Morrison learned as a writer and imparted to her readers in Beloved. In the first place, $A$ Mercy is reminiscent, in narrative structure and the process of narrative transmission, of Beloved, as becomes obvious considering the types of narrators, focalization, fragmentation of the plot, temporal layers, polyphony, etc. Secondly, A Mercy comes in tow of Beloved's uncompromising gaze into the gut of slavery-and it is a lot sketchier in that respect. Still, "A Mercy asks readers to consider what exactly initiates the racial ideology of American history" (Cox 107), while then depicting its bitter fruit in the plotlines of Beloved. However, a telling departure is observable in significantly reducing the role of the supernatural in the texture and the plot of A Mercy in comparison to Beloved. Even so, Morrison imaginatively joins the two texts by using the voice or assuming the perspective of the dead (narrators).

In A Mercy, the narrator is concerned with a semblance of historical accuracy. At the very beginning, we are provided with a contemporary map

7 Morrison, A Mercy: A Novel 165. All subsequent references are to this edition and will be given parenthetically in the text. 
of the mid-section of the North American Atlantic coast, the Chesapeake region, crisscrossed by the names of native tribes, showing the derivation of most geographical features on the map from aboriginal languages. As Beavers contends, in this early colonial period everything is still "inchoate" and "fluid," from racial codes, social relations, states, and maps (164-65, 169). (The novel does not encompass only parts of British America but also those of its contenders, thus evoking, explicitly, the Portuguese, i. e. Catholic, and the Dutch claims. Furthermore, a specific geographic distribution coupled with the regional political economy of the slowly but steadily consolidating institution of slavery is in evidence in the scattered references to Brazil and the Caribbean, where it paves the way for what Patterson lists as "the large-scale slave systems" in an Appendix to his 1982 study.) This indicates that, in the historical content presented in A Mercy, Morrison goes one step further, or rather, back in history-she clearly evokes and intends the primary, Indian, layer that was overlaid by subsequent interventions. The novel thus implicitly and explicitly engages an additional element of America's "original sin," not only slavery but also the genocidal treatment of the native population. Going back to the seventeenth century enables Morrison to do as much and to insist on a very specific link between two historical processes - the gradual introduction of slavery in North America and the attendant pursuit of the dispossession, displacement, and destruction of the native inhabitants (Babb 150). The intertwining of two formative narratives should be recognized also in the array of characters including the whites, the blacks, and the natives engaged in similar pursuits but in different roles, some as masters, others as servants or slaves.

As historians of slavery point out, the seventeenth century is crucial in that it was the period in which slavery gradually took hold of the continent and insinuated itself into civil, legal, and economic practices (Berlin 15-92). As the novel makes clear, it is still being experimented with and is not firmly, irrevocably tied to the notion of color or latched onto the (black) race. In other words, the novel fictionalizes the fall into slavery, the point where a so- 
ciety that could go either way chose, or was driven, to a specific form whose full-blown consequences are then dwelt upon in Beloved. In A Mercy, social, economic, and racial categories are still in flux. Willard and Scully, white indentured servants, begrudge a black blacksmith his free status; their initial solidarity with him crumbles away under the pressures both of race and social status. Arguably, and perhaps rightly so, given the turmoil of the European Great War, religious identities are of greater import than the color line, as observed in the interaction between the Catholics and the Protestants, different Protestant denominations, and heathens and Christians. Again, the imperial center radiates its divisions and attempts to impose and replicate them at the colonial periphery. Slowly, however, the issues of religion will become subsidiary to the issue of socio-economic taxonomy based on color. (In fact, it would be possible to argue that, given the fast rate and high accidence of intermingling, voluntary or coerced, between, provisionally speaking, blacks and whites in some regions of North America, the increased attention to color was necessary precisely to keep in check the process of eliding the racial difference, possibly leading to what Berlin throughout his book describes as a "creole society.") In other words, we see the beginning of a specific process of nation-building in North America that will eventuate in the formation of a new republic: the construction of a national subject becomes invested primarily in the notion of race as the factor of whiteness becomes the badge of a free civic (and economic) agent. ${ }^{8}$

In both $A$ Mercy and Beloved the transatlantic perspective is maintained as an important vantage point. In the former, Africa figures as a colony, a source of labor force, a site included in a triangular slave trade, thus a source of fabulous, unprecedented accumulation of wealth. D'Ortega is a greedy and lecherous Catholic slave trader who owes his economic rise to the trade in flesh, as Jacob Vaark muses. The Protestant Vaark at first refuses to deal di-

8 Dana Nelson's and Russ Castronovo's studies illustrate the key juncture of (implicit, now excavated) whiteness and nation-building. 
rectly in people but as a creditor still participates both in the slave trader's profit and losses, and eventually decides to ride the crest of the sugar boom in the Caribbean. While Maryland thrives on an alliance of tobacco and slavery, down south, sugar is the "kill-devil" ( $A$ Mercy 31), as vast sugar cane plantations swallow droves of slaves. The logic of greed and profit-making makes clear that the initial accumulation of capital, necessary to sustain economic activity in a new region (periphery) being incorporated into the economic system, needs slavery as its modus operandi. In light of this, the entanglement between the capitalist economy and the brazen and relentless exploitation of the work force in slavery should be understood not as an anomaly but, in fact, as a precondition for the boundless wealth and economic strength of the European powers and of a nation-to-be (Curtin 51-52). Slavery, and tangentially, other forms of stratification (religious, gender, social) underwrite the civilizing project in the New World.

Despite a cultural geography installed by the triangulated slave trade, colonization, and imperialism inevitably creating a creolizing culture, Africa is the only unadulterated place of origin claimed by the slave mothers in the novels and imparted to their progeny, usually daughters, as this formative but traumatized genealogy is examined by Rody (3-16). In A Mercy, concluding words are granted to the mother, who in Beloved is silenced through absence and death. Florens's mother wraps up the story by taking us to the beginning, to Africa, and recounting her passage from Africa to Barbados to North America. In such capacity, Africa is treated at greater length in Beloved, where the image is pursued more elaborately and consistently in Sethe's lineage-her mother was an African who survived the Middle Passage, embraced a fellow black man, and was able to impart a few words of her native tongue to her infant daughter, so that the grown-up Sethe remembers some of them (29-30, 57-59). Africa as a phantasmagoric place is rendered in Beloved's sections in the novel but is covered over by the traumatic passage, the impossibility of survival, and the subsequent deracination and depersonalization attending slaves at their destination (200-203). Even though supernatural elements are 
less prominent in A Mercy, they still prevail when it comes to the memory of slavery processed by one of the most mysterious characters, Sorrow. As a mongrelized child, born out of the sea and of unknown origin, she retains scraps of memories, entangled with dreams and nightmares, that testify to some previous traumas but also evoke a lasting myth-that of the Africans walking across the water back to the motherland. Sorrow, just like Beloved, may be said to contain some shreds of collective memory of the pre-slavery period.

\section{Gendering the History of the New World}

Critics have noted Morrison's preoccupation with African American families as heavily matriarchal and female-centered. ${ }^{9}$ Morrison herself admits as much in her interviews while she explains that such was the bent of her and other female writers' imagination responding to specific urgencies (Morrison, "A Bench" 38; Brown and Morrison 455-56; McKay and Morrison 421-22). Since for her it has been impossible to divorce the political and social from the ostensibly purely aesthetic, she maintains that the black woman's story had to be told at some point (Morrison, "Rootedness" 339-45). She has often had to respond to claims of herself marginalizing and excising black men from her fictional families, and consequently according undue attention to black women as mothers and matriarchs. Following the black family's record of engagement with slavery, emancipation, and post-emancipation in U.S. history, Morrison imagines variations, more compulsory than self-willed, which have made the African American family what it is, regardless of what a social sciences perspective would require it to be. ${ }^{10}$

9 For competent overviews of this well-known debate in African American criticism, see McDowell 75-97; Dubey, Black.

10 In this respect, most of her female-based households are in a sense her imaginative response to and refutation of the impact and reverberations of the controversial Moynihan report commissioned in 1965 by the U.S. Department of Labor (Moynihan). See Brown and Morrison 457; Dubey 1994: 14-32. 
The dynamics of history is relayed through an interesting positioning of female characters. Already in the third chapter, early on in the plot of A Mercy, Jacob Vaark, the patriarch, albeit benevolent and more progressive than most of his peers, is dead of pox. Thus, the running of the farm in the wilderness is left to a bevy of women including his wife Rebekka; Lina, a competent Native American who helped them set up the food production and farm management; Florence, a slave-girl whom Lina adopts; and finally, the moody and unpredictable orphan, Sorrow. The four women and soon-to-beborn Sorrow's baby do not make a likely winning combination on the frontier: "Female, illegal ... subject to purchase, hire, assault, abduction, exile," Lina muses (58). They make up a makeshift family, being existentially speaking all orphans, each marked by an individual loss symbolizing the shorthand of history (59). Another makeshift family in the novel is the bond between Willard and Scully, who against many odds set up an all-male household.

Yet another provisional family structure is temporarily created during Rebekka's crossing over from England to America, from girlhood to womanhood, from poverty and religious bigotry to relative comfort and freedom from religious restrictions. The beginning of her journey is not particularly auspicious; in fact, we could say that it constitutes her own kind of middle passage, being sold, in the manner of slaves, by her father to her future husband (74). Still, in comparison to stinky, filthy, crime- and blood-ridden England, America is more embracing of her as a woman, at first (78). During her passage, she bonds with a group of women who enact their own vision of self-invention in the New World.

On her deathbed, Rebekka evokes the idea of bonding and of the possibility extended also to women in the new country. This sense of empowerment continues on the farm reinforced by her initially tenuous but then firm connection with Lina. However, the ongoing tension bears also on the provisional communities - the characters, instead of sustaining long-term bonds, in the end succumb to betrayal of each other and to isolation. Rebek- 
ka lapses into the same kind of religious bigotry that pushed her away from Europe as she in the end dismisses her household help as "savages" (159). Willard and Scully fear the coming of a new master, who might continue to exploit their indentured status. Florens becomes intractable in her infatuation, enslavement to her passion for the blacksmith. Even on a small scale, a farm approximating a civilized state, the array of different characters can barely hold together and move beyond their differences, despite their little mercies (155-56).

While in her previous novels Morrison, in her own words, does not really care about either white characters or the white audience's gaze, and pointedly tries to escape them catering to her black audience, both in Beloved and more insistently in A Mercy, she moves towards an interracial feminine solidarity based on "cross-cultural encounters with women ... of other racial or ethnic groups" (Rody 12; Brown and Morrison 457; Morrison "Rootedness" 339-45). Beloved dramatizes this vantage point in an especially poignant revisiting of the episode of Denver's birth. The latter's name in fact commemorates her midwife, a white trash girl, Amy Denver, herself an escaped servant on the way to the North and freedom (30-33, 71-79). In A Mercy, Florens finds herself in a similar position. On her way to deliver her mistress's message to the blacksmith, she comes across a Puritan village and, black and foreign, is incriminated as a witch. We have seen in previous passages how this episode may be seen as constitutive of a transcendental rationale for the meaning of race. Yet in the context of my present concerns, this episode should also be seen as a temporary suspension of the divisive logic of race coupled with patriarchy since it transpires that Florens is saved by a white girl, a self-professed witch. Female witchery is an early and here the only alternative to the joint exigencies of religious, patriarchal, and racist systems. The act of mercy is also almost accidental and fleeting, just like the other acts of female bonding in the novel.

Even though it has been suggested at the beginning of this section 
that Morrison depicts strong female characters and all-female households, this is not to suggest that she adulates them. Quite on the contrary, A Mercy shows unsuccessful communication between the mother and the daughter. The entire book, its process of story-telling, is a testament to the mother's failure to nurture (due to slavery) and to the daughter's pain of loss (of the mother and the mother's love). The mother's voice, in her final address simultaneously the ultimate chapter of the narrative, pleads her case with the daughter, trying to explain what it was that made her give up her female child-and apparently hang on to her younger male child. But there is no way to ensure that Florens, the daughter, will hear the mother's words, since they fall outside her purview - her "sadness" in the end is a sign of failure (161). Besides, her story is deflected from the mother, even from her surrogate mother, Lina, and directed to her lover, the blacksmith and healer, who in the end forgoes her for another male child, his adoptive son. Florens once again becomes an orphan. As in Beloved, Morrison yet again questions the universal, the meaning of love, through a particular query - the implications of motherhood in slavery. Thus, the bond between the mothers and daughters is rendered ambiguous.

Baby Suggs from Beloved, a matriarch, preacher, and spiritual leader of the newly emancipated black community in Ohio, professes a specific theology of the flesh. She repeatedly exhorts her congregation, assembled almost $a d$ hoc in a clearing in the woods, while she occupies a stone altar in the middle, to tend to their bodies and body parts that were desecrated, reviled, and soiled in slavery (80-83). She urges the people to love their respective body parts in an attempt to counteract in the process of self-appreciation the devastating effects of spiritual death in slavery. ${ }^{11}$ While the immediate and

\footnotetext{
11 This is discussed in particular by sociologist Patterson (Slavery) and historian Nell Irvin Painter (Southern). Painter uses the term "soul murder" to account for the devastating psychological effects of enslavement on slaves. Saidiya Hartman's 1997 study also takes cognizance of the psychological toll of the manifold forms of enslavement as a constant daily regime of control, surveillance, and subjection.
} 
long-term healing import of such an exercise is not to be underestimated, in this section I would like to dwell more specifically on some other aspects of corporeality, bodily exigencies, the fleshly theology, and ultimately an epistemology based and stamped on the body, especially the black female body.

Initially, the wresting of an alternative history from the clutches of the sanctioned version takes place through the long-held opposition between the oral and the written. ${ }^{12}$ In addition, Fabre and O'Meally consider the practices of memorializing in African American history while proposing that African American cultural forms, from high to popular, are invested in an ongoing tension between history (pertaining to the written) and forms of memory (pertaining to orality) ("Introduction" 3-17). Such a continuous swerving back and forth contributes also to the project proposed by Beloved. Broadly speaking, the novel engages in forms of memory and its eventual and wayward crystallization into history. Before the arrival of Paul D to Sethe's house, she does her best to evade memories or to block them more or less effectively: "To Sethe, the future was a matter of keeping the past at bay" (40). Residual elements are possibly retained in the idea of haunting, and the disruptive presence of a ghost in the house, but this could at first be put down to family mystery, as is the wont of the gothic mode. Paul D not only unwittingly unclogs Sethe's memory lanes, but the encounter also causes his memory tinbox to open and pour its contents out (39). ${ }^{13}$

Thus, the first move is made, that of enabling remembering to occur, so that slavery may be committed to memory. At the same time, as is made clear with the disappearance of the "haint," the process of remembering entails mastery, a certain normalization of an extraordinary experience. This is what the materialization of the ghost testifies to: Sethe, Paul D, and Denver

12 For the orality/literacy binary in African American culture, see Morrison, "Rootedness"; McKay and Morrison, 421, 427; Dubey, Signs.

13 For the materiality of memory practices, see Yates 1-49. 
will not be allowed to settle into routine family ways as Beloved, the essence of slavery, materializes in flesh. At the same time, the exigencies she makes on all the characters exercise to the limit their memory and their cognitive and emotional capacities joined in the same goal: to remember slavery not simply as a domesticated part of one's personal narrative, an uplifting family tale, or a morale-boosting communal narrative, but as something in excess of all of these (172). This is why Paul D almost suffocates after he has copulated with Beloved: "And afterward, beached and gobbling air, in the midst of repulsion and personal shame, he was thankful for having been escorted to some oceandeep place he once belonged to" (250). This is why Sethe initially gleefully humors Beloved's repeated entreaties to tell stories (about herself and Beloved), only subsequently to be literally wasted and emaciated by Beloved's voraciousness for the past (237). This is why Denver has to break out of the circle and swap her immersion into the past for more immediate concerns.

Similarly, as Sethe and Denver are the first to realize Beloved's mixed potential, a similar recognition must take place on a larger scale for the process of memory to take its full course resulting in a communal consensus. Hence, community ought to identify Beloved and her multifarious capacity. When her presence exceeds the bounds of the enclosed domestic space of Baby Suggs's house, it is then that the implications of her role become public. The effect of her desire to know and press the characters into recalling and retelling slavery, and a fully disastrous effect of such a demand, must be reckoned with collectively. In the fluctuating definition of Beloved's complex role and in an attempt to define her, we see emerging a historical (and thus collective), shared, and cognitively validated experience.

The oral and orality stand represented in Beloved as sites of eruption of the folk, black people's life-forms (245). First, there are Beloved's repeated urgings of other characters to tell her stories, in order to feed her memory or to restore it. The next is the narrative's reliance on the dynamics, structure, and tempo of (oral) storytelling — some stories are imparted in the way 
they materialize for the characters in question (Denver's birth; the story of the flight from Sweet Plantation-as we patch it together from Paul D's and Sethe's jumbled recollections; part of Sethe's childhood; Sethe's secret); the fact that some of the stories are repetitive suggests that the novel is not interested so much in the event as such but more so in the form it takes for the event to turn into a story and to become narrativized, thus also part of the character's individual life-story, and to make sense for the characters and the reader. In that sense, as Sommer contends, Beloved is an experiment in story-telling and the circulation of stories (Beloved 151-57; Sommer, Proceed 160-84).

Other elements of the seeming privileging of orality over print and print literacy abound in the novel. We are reminded again of the fiendish, almost allegorical implications given to the ink and Schoolteacher's educational efforts. Next, we ought to consider the devastating effect of the newspaper item that shatters Paul D's complacent belief in the price of Sethe's escape from Sweet Home. As Stamp Paid realizes that Paul D is unaware of Sethe's story (the family is isolated from the rest of the community, and the story does not circulate), he decides to show Paul D the article depicting the murder and attempted murder of her children committed by Sethe. Paul D winces from the print, rightly guessing that only an outrage would put a black woman into the papers, as in the next instant, Sethe's story unfolds before him in the form of a folded piece of newspaper (147-48). Paul D is also the one who, towards the end of the novel, voices once again his skepticism of the role of letters in black people's emancipation, but his doubt is precisely what sets him apart from Denver's confidence and desire to learn her letters and eventually go to college. As Paul D sees it, Halle, Denver's father, who got stuck on the Kentucky plantation and lost his mind there, had no use for letters and numbers, while for him letters only meant the transfer of ownership on the deeds of sale, so that the print only signified the extension of the white man's power over blacks (252). 
Another instance that corroborates the incipient connection between orality and African American culture is the element of performativity that also repudiates the fixity and stability of a written record and instead engages the context and the participants in a performance. For Morrison, the energy of performance and non-fixed genres infuses her writing in an attempt to approximate the black expressive forms (McKay and Morrison 426-27). Granted, both orality and performativity are central to the notion of African American culture in the Americas, but the drift of my argument in this section requires that they be associated with and explicitly attributed to black women, as agents, participants, subjects, and sufferers in historical configurations of the New World. We have seen the mother's line necessarily more pronounced in the imbalance created by the reproductive law of slavery- the children follow the condition of the mother. In addition, only the mother is certain, or as suggested by Hortense Spillers, "mama's baby, papa's maybe" illustrates the perversion of the family principle in slavery (64-81). Sethe's children are fathered by a black slave, who is left behind to languish in Kentucky, while she plunges on towards freedom.

The attendant ambiguity of the notion of gendering as a viable vehicle of historical imagination is thus echoed in criticism, and for reasons that exceed that of real, concrete impediments posed by slavery. Madhu Dubey has recently expressed some reservations about conveniently collapsing the idea of black culture with the notions of orality and performance, at the expense of situating the black cultural formations in the context of changes wrought by postmodernity (Signs 1-16). Similarly, Ying seems to agree that to manage "a written form" would empower the African American culture, which is mostly oral and aural (45).

Thus, in A Mercy, Florens' origin is "mongrelized" as her mother was broken in by the traders, a standard practice that institutes the widespread process of blood-crossing. The novel is framed by Florens' opening and her mother's closing chapter. In-between, an impersonal but intrusive narrator 
intervenes. The space for the daughter's agency and voice, thus the very prerequisites of her story and history, are literally and symbolically provided by the mother, who exacts an act of mercy from an unwilling Protestant trader. Motherly devotion, a mother's act of unconditional love, grounds the daughter's existence and lays way for the entire story. Theirs is the communication that transcends the bounds of place and time. In a similar way, the intertwined voices of three women, Sethe and her two daughters, Denver and Beloved, form the closing choral section of Beloved (190-207). While Beloved still inclines more towards orally transmitted stories, A Mercy takes a more complex view of the matter. The latter novel is built on the intermingling of the oral and literary modes of story-telling. Even as Florens' urgent voice acts as a story-generating vehicle, in the end, she makes clear that her words need also to be written down. Her story, the story of the weird family in the New World semi-wilderness constituted by acts of random humanity and disrupted by equally gratuitous acts of human cruelty, moves between the urgency of being seen — that is, read — and the necessity of being heard (160-61).

\section{Bridging the Gap}

Avowedly, Morrison swerves between two positions in her assessment of literature and its role. At first, she seems to suggest that it is a language of universals. She says as much, for instance, in her Nobel speech prize, where she pronounces on the role and impact of literature primarily through its specific handling of language, while its meaning must also reside in and arise from an interaction between the writer and her audience ("Toni Morrison Nobel Lecture”). Secondly, however, she proposes that a universal critical, supposedly humanistic, position as a vantage point from which to evaluate texts is impossible and unfeasible: her world is genderized, sexualized, and racialized (Morrison, Playing 4). This is by way of rephrasing the dilemma outlined at the beginning of the text, namely, by questioning to what extent an African American female author breaks out of the mold of the marginal discourse and, more importantly, when does she reach that entitlement, Mor- 
rison, clearly, has achieved this in a way that other African American, ethnic, and female authors could not dream of without having given up in the process on her particular characters and their peculiar plight.

In order to illuminate what might be for Morrison a productive giveand-take between the universal and the particular that we find in her texts, themes, narrative style, and language use, but most of all in her ideology, I would like to evoke Doris Sommer's concept of a resistant text, one that refuses to grant easy gratification to the reader. Sommer proposes this within the scope of "minority writing in the Americas," where she herself works with the spatial logic of marginality and centrality already evoked in my argument: "the powerful center can mistake its specificity for universality," so that it may take precisely "a resistant text" and its "ethico-aesthetic strategy" to break up this arrangement (Sommer, Proceed 8-10). A resistant text, according to Sommer's model, "announc[es] limited access," holds back information, refuses to alleviate the reader's limited understanding or competence, and "place $[\mathrm{s}]$ traditionally privileged readers beyond a border" (10). She also works with the term "particularist fictions," designating texts which enjoin us as readers to observe "an ethical distance from the object of desire," obviating a full hermeneutical disclosure of the text (31). In line with this, Sommer calls those writers "particularist[s]" who produce "reticent texts" containing "signs that make a political as well as an aesthetic difference" (15-16). This, in short, would be a very suitable description of Morrison's writing agenda.

In other words, Morrison's novels, by engaging an ethnic, and thus by default and convention a marginal, oblique, and unseen experience, in fact humanize and universalize it to such an extent that they ultimately make the issue of race and gender secondary to the notions of human psychology, emotionality, and cognition. In the process, however, they show how and why these "particulars" must be and have already been factored into our being in the world. One wonders whether this might not be one of Morrison's foremost achievements - allowing us to forget, at least for the duration of 
reading, the more implacable conditions of our existence and enabling us to conjure the ways and modes in which we could exist and think otherwise, crossing the lines so that eventually we lose sense of presumed centers and proverbial margins.

\section{Works Cited}

Babb, Valerie. "'E Pluribus Unum?' The American Origins Narrative in Toni Morrison's A Mercy." MELUS, vol. 36, no. 2, Toni Morrison: New Directions, 2011, pp. 147-64.

Beavers, Herman. Geography and the Political Imaginary in the Novels of Toni Morrison.

Palgrave Macmillan, 2018.

Berlin, Ira. Many Thousands Gone: The First Two Centuries of Slavery in North America. The Belknap P of Harvard UP, 1998.

"Black Writers in Praise of Toni Morrison." The New York Times. 24 Jan. 1988, www. nytimes.com/books/98/01/11/home/15084.html. Accessed 14 March 2020. Blaut, J. M. Colonizer's Model of the World: Geographical Diffusionism and Eurocentric History. The Guilford P, 1993.

Brown, Cecil, and Toni Morrison. "Interview with Toni Morrison." The Massachusetts Review, vol. 36, no. 3, 1995, pp. 455-73.

Byerman, Keith. "Remembering History in Contemporary Black Literature and Criticism." American Literary History, vol. 3, no. 4, 1991, pp. 809-16.

Carby, Hazel. "Ideologies of Black Folk: The Historical Novel of Slavery." Slavery and the Literary Imagination, edited by Deborah E. McDowell and Arnold Rampersad, The Johns Hopkins UP, 1989, pp. 125-43.

Castronovo, Russ. Fathering the Nation: American Genealogies of Slavery and Freedom. U of California P, 1996.

Coates, Ta-Nehisi. "Foreword by Ta-Nehisi Coates." The Origin of Others, by Toni Morrison, Harvard UP, 2017, pp. vii-xvii.

Cox, Sandra. "Mother Hunger: Trauma, Intra-Feminine Identification, and Women's

Communities in Toni Morrison's Beloved, Paradise, and A Mercy." Contested Boundaries: New Critical Essays on the Fiction of Toni Morrison, edited by Maxine L.

Montgomery, Cambridge Scholars Publishing, 2013, pp. 96-123.

Curtin, Philip D. The Atlantic Slave Trade, A Census. The U of Wisconsin P, 1969. 
Doyle, Laura. Freedom's Empire: Race and the Rise of the Novel in Atlantic Modernity, 16401940. Duke UP, 2008.

Dubey, Madhu. Black Women Novelists and the Nationalist Aesthetic. Indiana UP, 1994.

---. Signs and Cities: Black Literary Postmodernism. The U of Chicago P, 2003.

Eyerman, Ron. Cultural Trauma: Slavery and the Formation of African American Identity. Cambridge UP, 2001.

Fabre, Geneviève, and Robert O'Meally, editors. History and Memory in African-American Culture. Oxford UP, 1994.

Fisher, Philip. Hard Facts: Setting and Form in the American Novel. Oxford UP, 1985.

Gates, David. “Original Sins. Review of A Mercy, by Toni Morrison.” New York Times Book Review. 30 Nov. 2008, www.nytimes.com/2008/11/30/books/review/Gatest.html. Accessed 9 Apr. 2020.

Goldberg, David Theo. Racist Culture: Philosophy and the Politics of Meaning. Blackwell, 1993.

Hartman, Saidiya. Scenes of Subjection: Terror, Slavery, and Self-Making in Nineteenth-Century America. Oxford UP, 1997.

Henderson, Mae G. “Toni Morrison's Beloved: Re-Membering the Body as Historical Text.” Toni Morrison's Beloved: A Casebook, edited by William L. Andrews and Nellie Y. McKay, Oxford UP, 1999, pp. 79-106.

Levander, Caroline F. Where Is American Literature? Wiley and Blackwell, 2013. Lukács, Georg. The Historical Novel (excerpts). Theory of the Novel: A Historical Approach, edited by Michael McKeon, The Johns Hopkins UP, 2000, pp. 219-64.

McDowell, Deborah E. "Reading Family Matters." Changing Our Own Words: Essays on Criticism, Theory, and Writing by Black Women, edited by Cheryl Wall, Rutgers UP, 1989, pp. 75-97.

McDowell, Deborah E., and Arnold Rampersad, editors. Slavery and the Literary Imagination. The Johns Hopkins UP, 1989.

McKay, Nellie, and Toni Morrison. "An Interview with Toni Morrison." Contemporary Literature, vol. 24, no. 4, 1983, pp. 413-29.

Mitgang, Herbert. "For Morrison, Prize Silences Gossip." The New York Times. 1 Apr. 1988, www.nytimes.com/books/98/01/11/home/15522.html. Accessed 14 March 2020. Montgomery, Maxine L. Contested Boundaries: New Critical Essays on the Fiction of Toni 
Morrison. Cambridge Scholars Publishing, 2013.

Morrison, Toni. Beloved. 1987. Penguin, 2000.

---. "A Bench by the Road: Beloved." The World, Jan/Feb 1989, pp. 4-5, 37-41.

---. A Mercy. A Novel. Alfred Knopf, 2008.

---. Playing in the Dark: Whiteness and the Literary Imagination. 1992. Vintage

Books, 1993.

---. "Rootedness: The Ancestor as Foundation." Black Women Writers (1950-1980): A

Critical Evaluation, edited by Mari Evans, Anchor Books, Doubleday, 1984, pp. 339-45.

---. “Toni Morrison Nobel Lecture.” 7 Dec. 1993, www.nobelprize.org/prizes/

literature/1993/morrison/lecture/. Accessed 15 June 2020.

Moynihan, Daniel P. “The Negro Family: The Case for National Action.” U.S. Department of Labor, March 1965, www.dol.gov/general/aboutdol/history/webid-moynihan. Accessed 27 Aug. 2020.

Mudgett, Kathryn. “The Natural and Legal Geographies of the Body: Law's Corpus Written on the Lives of Sethe and Florens." Contested Boundaries: New Critical Essays on the Fiction of Toni Morrison, edited by Maxine L. Montgomery, Cambridge Scholars Publishing, 2013, pp. 67-80.

Nelson, Dana. National Manhood: Capitalist Citizenship and the Imagined Fraternity of White Men. Duke UP, 1998.

Nicol, Kathryn, and Jennifer Terry. “Guest Editors' Introduction. Toni Morrison: New Directions.” MELUS, vol. 36, no. 2, Toni Morrison: New Directions, 2011, pp. 7-12.

Omi, Michael, and Howard Winant. Racial Formation in the United States: From the 1960s to the 1990s. 2nd ${ }^{e d}$. Routledge, 1994.

Page, Philip. Dangerous Freedom: Fusion and Fragmentation in Toni Morrison's Novels.

UP of Mississippi, 1995.

Painter, Nell Irvin. Southern History across the Color Line. The U of North Carolina P, 2002. Patterson, Orlando. Slavery and Social Death: A Comparative Study. Harvard UP, 1982.

Rody, Caroline. The Daughter's Return: African-American and Caribbean Women's Fictions of History. Oxford UP, 2001.

Rosenfeld, Paul. "Why America Needs a Slavery Museum." The Atlantic. 25 Aug. 2015, www.theatlantic.com/video/index/402172/the-only-american-museum-about- 
slavery/. Accessed 1 July 2020.

Rushdy, Ashraf. “Daugthers Signifyin(g) History: The Example of Toni Morrison's

Beloved." American Literature, vol. 64, no. 3, 1992, pp. 567-97.

---. Neo-Slave Narratives: Studies in the Social Logic of a Literary Form. Oxford UP, 1999.

Sandy, Mark. "'Cut by Rainbow': Tales, Tellers, and Reimagining Wordsworth's Pastoral

Poetics in Toni Morrison's Beloved and A Mercy." MELUS, vol. 36, no. 2, Toni

Morrison: New Directions, 2011, pp. 35-51.

Sommer, Doris. Foundational Fictions: The National Romances of Latin America.

U of California P, 1991.

---. Proceed with Caution, When Engaged by Minority Writing in the Americas.

Harvard UP, 1999.

Spillers, Hortense J. “Mama’s Baby, Papa’s Maybe: An American Grammar Book.”

Diacritics, vol. 17, no. 2. Culture and Countermemory: The "American" Connection, 1987, pp. 64-81.

Stepto, Robert, and Toni Morrison. “'Intimate Things in Place': A Conversation with Toni

Morrison." The Massachusetts Review, vol. 18, no. 3, 1977, pp. 473-89.

Tally, Justine, editor. The Cambridge Companion to Toni Morrison. Cambridge UP, 2007.

Tedder, Charles. "Post-Racialism and Its Discontents: The Pre-National Scene in Toni Morrison's A Mercy." Contested Boundaries: New Critical Essays on the Fiction of Toni Morrison, edited by Maxine L. Montgomery, Cambridge Scholars Publishing, 2013, pp. 144-59.

Uncensored: Toni Morrison. Films for the Humanities and Sciences. Dir. Gary Deans.

Australian Broadcasting Corporation, 1998.

“The United States National Slavery Museum.” Wikipedia: The Free Encyclopedia,

Wikimedia Foundation, 10 Sept. 2020, 2:39 UTC, en.wikipedia.org/wiki/United

States_National_Slavery_Museum. Accessed 5 July 2020.

Wagner Martin, Linda. Toni Morrison: A Literary Life. Palgrave Macmillan, 2015.

Wall, Cheryl. "Toni Morrison: editor and teacher." The Cambridge Companion to Toni

Morrison, edited by Justine Tally, Cambridge UP, 2007, pp. 139-48.

Yates, Frances A. The Art of Memory. The U of Chicago P, 1966.

Ying, Zhu. Fiction and the Incompleteness of History: Toni Morrison, V.S. Naipaul, and Ben 